\title{
Core elements of general supportive care for patients with sepsis and septic shock in resource-limited settings
}

\author{
Mervyn Mer ${ }^{1,2^{*}}$ (D), Marcus J. Schultz ${ }^{3,4,5}$, Neill K. Adhikari, ${ }^{6,7}$ and For the European Society of Intensive Care \\ Medicine (ESICM) Global Intensive Care Working Group and the Mahidol-Oxford Research Unit (MORU), \\ Bangkok, Thailand
}

(c) 2017 The Author(s). This article is an open access publication

\section{Introduction}

Evidence informing the management of patients with sepsis and septic shock mainly derives from research in resource-rich settings. Knowledge translation to intensive care units (ICUs) in resource-limited settings is limited by restricted availability of skilled staff, equipment, and laboratory support, compounded by infrastructure and logistical challenges. Consequently, we developed recommendations relating to core elements of general supportive care for patients with sepsis and septic shock in resource-limited settings. Our recommendations are built on guidelines from the Surviving Sepsis Campaign [1] and the Global Intensive Care Working Group of the European Society of Intensive Care Medicine [2], as well as on a search for additional recent evidence from resource-limited ICUs.

Clinicians with direct experience in resource-limited ICUs developed recommendations by adapting the Grading of Recommendations Assessment, Development and Evaluation (GRADE) tools [3]. Similar to our group's previous publications (e.g., see [4]), quality of evidence was assessed as high to very low. Recommendations were stated as strong or weak on the basis additionally of indirectness of evidence, magnitude of effects, and availability, feasibility, and safety in resource-limited ICUs. We consulted the World Health Organization

\footnotetext{
*Correspondence: mervyn.mer@wits.ac.za

${ }^{1}$ Divisions of Critical Care and Pulmonology, Department of Medicine, Charlotte Maxeke Johannesburg Academic Hospital and Faculty of Health Sciences, University of the Witwatersrand, Johannesburg, South Africa Full author information is available at the end of the article

Members of the Sepsis in Resource-Limited Settings Group are listed in the online supplement.
}

Essential Medicines List when considering availability of medications (available at http://www.who.int/medicines/ publications/essentialmedicines/en/). When necessary, evidence from resource-rich ICUs was adopted after pragmatic experience-based appraisal (see online supplement). We also made several good practice statements [5].

\section{Results and recommendations}

The literature search for additional evidence from resource-limited ICUs identified several guidelines [6-8]; the only randomized trials were of metformin for the treatment of hyperglycemia [9-11]. Key recommendations are provided in Table 1. Considerations informing each recommendation are described below; more detailed information on the literature search and grading of recommendations is included in the online supplement.

\section{Corticosteroids}

Low-dose corticosteroids are readily available and inexpensive; current evidence supports their use in septic patients with refractory shock, pending completion of additional trials (NCT00625209, NCT01448109). Data from recent systematic reviews suggest no increased risk of gastrointestinal bleeding, superinfection, or neuromuscular weakness, but a possible increased risk of hyperglycemia and hypernatremia. We did not locate trials or relevant observational studies from low-resource ICUs.

\section{Sedation for ventilated patients}

Relevant considerations include availability of selected opiates and benzodiazepines (although available in

\section{勿


principle, actual availability may vary); the requirement for nursing and medical expertise in the administration and monitoring of sedation to care for mechanically ventilated patients with sepsis; and the potential for delayed recognition of and physician response to a self-extubated patient requiring reintubation, particularly outside of weekday daytime hours. Existing literature largely derives from ICUs with high-intensity nurse staffing, reinforcing the need for caution with lighter sedation strategies in ICUs with fewer nurses.

\section{Neuromuscular blockade for ventilated patients}

Selected neuromuscular blocking agents are available in principle in resource-limited settings, although actual availability may vary. Unresolved issues include method of administration (bolus vs. continuous, which may increase complexity and costs) and monitoring via nerve stimulator vs. clinical judgment. Attentive nursing is required to care for patients receiving neuromuscular blockade. We did not locate trials or relevant observational studies from low-resource ICUs but expect additional data (NCT02509078) to inform this question.

\section{Venous thromboembolism prophylaxis}

Pharmacological prophylaxis is generally available in resource-limited ICUs and can be delivered feasibly and safely. Less available mechanical modalities may further decrease thromboembolism risk in combination with pharmacological prophylaxis and are potentially reusable. We identified one relevant guideline [8].

\section{Stress ulcer prophylaxis}

Proton pump inhibitors and histamine- 2 receptor antagonists are generally available in resource-limited ICUs and can be delivered feasibly and safely. Increased risks of ventilator-associated pneumonia and Clostridium difficile infection are not definitively established. We did not locate trials or relevant observational studies from low-resource ICUs; risks and benefits will be informed by additional trials (NCT02467621; NCT02290327).

\section{Glycemic control}

We identified a recent Indian consensus guideline on blood glucose management [7] and three small Iranian trials of metformin [9-11]. Critical illness-associated hyperglycemia is common, and short-acting insulin is widely available and inexpensive. However, blood glucose control with continuous intravenous insulin is a complex intervention, with an increased risk for hypoglycemia when monitoring is insufficient. Frequent blood glucose measurements may only be feasible with capillary blood testing, a method that is less accurate than venous or arterial sampling. We make no recommendations regarding metformin in the absence of adequate randomized trial evidence and concern over the risk of lactic acidosis.

\section{Enteral nutrition}

Enteral feeding is feasible and readily available. Where commercial feeds are not available or expensive, hospitalprepared foods may be administered. Parenteral nutrition is not routinely available. One small trial of early vs. later nasogastric nutrition in ward patients with malaria and depressed consciousness found an increased aspiration risk, but no trials or observational studies from low-resource ICUs were identified. We note some controversy among published guidelines regarding the timing and amount of enteral feeding.

\section{Renal replacement therapy}

Current guidelines do not address the choice of renal replacement modality. Recent observational literature has emphasized the high potential for feasible and costeffective widespread deployment of peritoneal dialysis (PD) to very low resource settings, notwithstanding challenges of patient selection, ongoing training, and program sustainability [12].

\section{Restrictive fluid management in patients no longer in shock}

Current guidelines make recommendations for initial fluid resuscitation, but not for fluid management in patients who are no longer in shock. We did not find trials of conservative fluid strategies from resource-limited ICUs. Challenges in designing such trials include managing trade-offs between complex protocols that consider individual patient physiology and practical limitations of monitoring technologies and frequency of clinical reassessments. 
Table 1 Recommendations for core elements of general support for septic patients in resource-limited ICUs $\begin{array}{lll}\text { Topic } & \text { Recommendation } & \text { Relationship to other guidelines }\end{array}$

Corticosteroids We suggest intravenous hydrocortisone (200 mg per day, or equivalent dose of

Same as SSC [1] another corticosteroid) in adult patients with septic shock, who despite both adequate fluid resuscitation and vasopressor support remain hemodynamically unstable (low quality of evidence)

Remarks Hemodynamic instability may be defined by systolic blood pressure less than $90 \mathrm{mmHg}$ for more than $1 \mathrm{~h}$ despite adequate fluid and vasopressor therapy. Hydrocortisone can be administered by continuous infusion or boluses for 5-7 days, or up to the weaning of vasopressor therapy, followed by tapering of the dose as guided by the clinical response. Bolus dosing does not require an infusion pump and is therefore more feasible. Dosing and pharmacokinetic properties of various corticosteroids are presented in supplementary Table 3

\begin{tabular}{|c|c|c|}
\hline Sedation & $\begin{array}{l}\text { The group believes that continuous or intermittent sedation should be minimized } \\
\text { in mechanically ventilated sepsis patients, targeting specific titration end points } \\
\text { from sedation scales (ungraded good practice statement) } \\
\text { Remarks Management of intravenous sedation for mechanically ventilated septic } \\
\text { patients requires attentive nursing and medical expertise and sufficient staffing } \\
\text { to handle risks of agitated delirium and device removal. Adequate pain control } \\
\text { should be attained in all patients where necessary (analgesia-first sedation), and } \\
\text { lighter sedation targets aimed for in general }\end{array}$ & Same as SSC [1] \\
\hline \multirow[t]{3}{*}{$\begin{array}{l}\text { Use of neuromuscular } \\
\text { blocking agents }\end{array}$} & $\begin{array}{l}\text { We suggest neuromuscular blockade for a maximum of } 2 \text { days in mechanically } \\
\text { ventilated septic patients with ARDS and } \mathrm{PaO}_{2} / \mathrm{FiO}_{2} \text { ratio }<150 \mathrm{mmHg}\left(\mathrm{SpO}_{2} / \mathrm{FiO}_{2}\right. \\
\text { ratio }<190) \text { (moderate quality of evidence) } \\
\text { Remarks Attentive nursing and medical care are essential requirements to care } \\
\text { for patients on neuromuscular blockade. We suggest monitoring the depth of } \\
\text { blockade through train-of-four-stimulation when neuromuscular blocking agents } \\
\text { are administered by continuous infusion. The safety of continuous neuromuscu- } \\
\text { lar blockade in the absence of capnography or arterial blood gas analysis is not } \\
\text { established }\end{array}$ & Same as SSC [1] \\
\hline & $\begin{array}{l}\text { The group believes that neuromuscular blocking agents should not be adminis- } \\
\text { tered when sedation and analgesia can prevent patient-ventilator dyssynchrony } \\
\text { (ungraded good practice statement) }\end{array}$ & Not addressed \\
\hline & $\begin{array}{l}\text { The group believes that sedation and analgesia should be used before and during } \\
\text { neuromuscular blockade to achieve deep sedation (ungraded good practice } \\
\text { statement) }\end{array}$ & Same as recent guideline [14] \\
\hline \multirow[t]{5}{*}{$\begin{array}{l}\text { Venous thromboembolism } \\
\text { prophylaxis }\end{array}$} & $\begin{array}{l}\text { We recommend UFH or LMWH to prevent VTE in patients with no contraindica- } \\
\text { tions to these medications (moderate quality of evidence) }\end{array}$ & Same as SSC [1] \\
\hline & $\begin{array}{l}\text { We recommend LMWH over UFH in patients with no contraindications to LMWH, } \\
\text { assuming availability of both medications (moderate quality of evidence) }\end{array}$ & Same as SSC [1] \\
\hline & $\begin{array}{l}\text { We suggest mechanical VTE prophylaxis when UFH and LMWH are contraindicated } \\
\text { or unavailable (low quality of evidence) } \\
\text { Remarks Mechanical prophylaxis includes GCS and IPC devices; GCS may be less } \\
\text { effective that IPC devices but are far more likely to be available }\end{array}$ & Same as SSC [1] \\
\hline & $\begin{array}{l}\text { We suggest a combination of mechanical and pharmacologic prophylaxis if pos- } \\
\text { sible (low quality of evidence) } \\
\text { Remarks Same as for previous recommendation }\end{array}$ & Same as SSC [1] \\
\hline & $\begin{array}{l}\text { The group believes that VTE prophylaxis should be continued until the patient is } \\
\text { fully mobile (ungraded good practice statement) }\end{array}$ & Similar to recent guideline [8] \\
\hline \multirow[t]{2}{*}{ Stress ulcer prophylaxis } & $\begin{array}{l}\text { We recommend that stress ulcer prophylaxis be given to patients with sepsis or } \\
\text { septic shock with risk factors for Gl bleeding (low quality of evidence) } \\
\text { Remarks Risk factors for Gl bleeding include mechanical ventilation for } \geq 48 \mathrm{~h} \text {, } \\
\text { coagulopathy, renal replacement therapy, liver disease, multiple comorbidities, } \\
\text { and higher organ failure score }\end{array}$ & Same as SSC [1] \\
\hline & $\begin{array}{l}\text { We suggest that either PPIs or H2RAs be used for stress ulcer prophylaxis (low qual- } \\
\text { ity of evidence) }\end{array}$ & Same as SSC [1] \\
\hline
\end{tabular}


Table 1 continued

\begin{tabular}{|c|c|c|}
\hline Topic & Recommendation & Relationship to other guidelines \\
\hline \multirow[t]{4}{*}{$\begin{array}{l}\text { Blood glucose } \\
\text { management }\end{array}$} & $\begin{array}{l}\text { We recommend a protocolized approach to blood glucose management in } \\
\text { ICU patients with sepsis, commencing when blood glucose is }>180 \mathrm{mg} / \mathrm{dL} \\
\text { (>10 mmol/L), with a target blood glucose value of } \leq 180 \mathrm{mg} / \mathrm{dL}(\leq 10 \mathrm{mmol} / \mathrm{L}) \\
\text { (high quality of evidence) }\end{array}$ & Same as SSC [1] \\
\hline & $\begin{array}{l}\text { The group believes that blood glucose levels obtained with finger stick blood } \\
\text { glucose tests be interpreted with caution, as these measurements may not accu- } \\
\text { rately estimate arterial blood or plasma glucose values (ungraded good practice } \\
\text { statement) }\end{array}$ & Same as SSC [1] \\
\hline & $\begin{array}{l}\text { The group believes that a simple protocol for blood glucose management should } \\
\text { be implemented for all critically ill patients, but only if frequent blood glucose } \\
\text { monitoring is feasible, safe, and affordable (ungraded good practice statement) }\end{array}$ & Same as recent guideline [7] \\
\hline & $\begin{array}{l}\text { The group believes that insulin should be administered intravenously rather than } \\
\text { subcutaneously in ICU patients with sepsis (ungraded good practice statement) }\end{array}$ & Not addressed \\
\hline \multirow[t]{4}{*}{ Enteral feeding } & $\begin{array}{l}\text { We suggest early enteral feeding as tolerated in patients with sepsis and septic } \\
\text { shock (low quality of evidence) } \\
\text { Remarks Additional considerations include starting oral or enteral intake within } \\
24-48 \mathrm{~h} \text { in adequately resuscitated and hemodynamically stable patients; taking } \\
\text { measures to reduce the risk of aspiration; and being aware of the refeeding syn- } \\
\text { drome in the first few days following enteral nutrition initiation in severely mal- } \\
\text { nourished or starved patients. The risk of aspiration may be increased in enterally } \\
\text { fed non-intubated comatose patients with inadequate nursing supervision }\end{array}$ & Same as SSC [1] \\
\hline & $\begin{array}{l}\text { We suggest either early trophic/hypocaloric or early full enteral feeding in critically } \\
\text { ill patients with sepsis or septic shock; if trophic/hypocaloric feeding is the initial } \\
\text { strategy, then feeds should be advanced according to patient tolerance (moder- } \\
\text { ate quality of evidence) } \\
\text { Remarks We suggest advancing feeds over the first week of ICU stay and note that } \\
\text { many patients in low-resource ICUs would be expected to be at high nutrition } \\
\text { risk/malnourished, and therefore likely to benefit from full enteral feeding }\end{array}$ & Same as SSC [1] \\
\hline & $\begin{array}{l}\text { We suggest establishing the energy and protein requirements to determine } \\
\text { the goals of nutrition therapy using weight-based equations (low quality of } \\
\text { evidence) }\end{array}$ & Consistent with recent guideline [15] \\
\hline & $\begin{array}{l}\text { We suggest a feeding protocol to optimize delivery of EN (moderate quality of } \\
\text { evidence) }\end{array}$ & Consistent with recent guideline [15] \\
\hline Renal replacement therapy & $\begin{array}{l}\text { We suggest that patients with sepsis-induced AKI requiring renal replacement } \\
\text { therapy be supported with PD in centers with no current access to renal replace- } \\
\text { ment therapy (very low quality of evidence; case series only) } \\
\text { Remarks In centers with functioning IHD programs, we suggest that this modality } \\
\text { continue to be used }\end{array}$ & Not addressed \\
\hline Fluid administration & $\begin{array}{l}\text { We suggest conservative fluid administration in patients with sepsis who are not } \\
\text { in shock (low quality of evidence; indirect evidence from trials in other forms of } \\
\text { critical illness) } \\
\text { Remarks Conservative fluid administration requires development of a protocol (e.g., } \\
\text { incorporating shock, oliguria, jugular venous pressure, capillary refill; see supple- } \\
\text { ment for reference to a sample resuscitation protocol incorporating some clinical } \\
\text { signs). The protocol should specify the timing of re-evaluation between fluid } \\
\text { interventions determined by patient stability. No de-resuscitation protocol has } \\
\text { been tested in low-resource ICUs. The role of pressure monitoring via a central } \\
\text { venous catheter to direct resuscitation and de-resuscitation is contentious. Con- } \\
\text { servative fluid administration may be associated with higher levels of blood urea } \\
\text { nitrogen, bicarbonate, hemoglobin, and albumin }\end{array}$ & Not addressed \\
\hline
\end{tabular}

Focused attention and careful evaluation of safety aspects and costs should be a consideration in every patient and in all settings

$A K I$ acute kidney injury, ARDS acute respiratory distress syndrome, $E N$ enteral nutrition, GCS graduated compression stockings, $G /$ gastrointestinal, $H 2 R A$ histamine-2 receptor antagonist, ICU intensive care unit, IHD intermittent hemodialysis, IPC intermittent pneumatic compression, LMWH low molecular weight heparin, $P D$ peritoneal dialysis, PPI proton pump inhibitor, SSC Surviving Sepsis Campaign, UFH unfractionated heparin, VTE venous thromboembolism 


\section{Conclusion}

We present recommendations for core elements of general supportive care of patients with sepsis or septic shock in resource-limited ICUs, incorporating considerations of availability, feasibility, affordability, and safety. The paucity of evidence from resource-limited settings underscores the urgent need for rigorous trials, since treatment effects may differ from trials conducted in high-income settings [13]. Given the immense variability in healthcare worker and technical capacity within resource-limited ICUs, we recognize that clinicians may have to further adapt this set of recommendations on the basis of site-specific circumstances.

\section{Electronic supplementary material}

The online version of this article (doi:10.1007/s00134-017-4831-z) contains supplementary material, which is available to authorized users.

\begin{abstract}
Author details
${ }^{1}$ Divisions of Critical Care and Pulmonology, Department of Medicine, Charlotte Maxeke Johannesburg Academic Hospital and Faculty of Health Sciences, University of the Witwatersrand, Johannesburg, South Africa. ${ }^{2}$ Wits-UQ Critical Care Infection Collaboration, Faculty of Health Sciences, University of the Witwatersrand, Johannesburg, South Africa. ${ }^{3}$ Department of Intensive Care, Academic Medical Center, University of Amsterdam, Amsterdam, The Netherlands. ${ }^{4}$ Laboratory of Experimental Intensive Care and Anesthesiology (L.E.I.C.A.), Academic Medical Center, University of Amsterdam, Amsterdam, The Netherlands. ${ }^{5}$ Mahidol-Oxford Research Unit (MORU), Faculty of Tropical Medicine, Mahidol University, Bangkok, Thailand. ${ }^{6}$ Department of Critical Care Medicine, Sunnybrook Health Sciences Centre, Toronto, ON, Canada. ${ }^{7}$ Interdepartmental Division of Critical Care, University of Toronto, Toronto, ON, Canada.
\end{abstract}

\section{Acknowledgements}

Group members of the Core Elements of General Supportive Care Subgroup: Mervyn Mer (Charlotte Maxeke Johannesburg Academic Hospital and Faculty of Health Sciences, University of the Witwatersrand, Johannesburg, South Africa), Marcus J. Schultz (Academic Medical Center, University of Amsterdam, Amsterdam, the Netherlands \& Faculty of Tropical Medicine, Mahidol University, Bangkok, Thailand), Neill K.J. Adhikari (Sunnybrook Health Sciences Centre \& University of Toronto, Toronto, ON, Canada), Arthur Kwizera (Mulago National Referral Hospital, Kampala, Uganda), David Misango (Aga Khan University Hospital, Nairobi, Kenya), Sanjib Mohanti (Ispat General Hospital, Rourkela, Sundargarh, Odisha, India), Arjen Dondorp (Faculty of Tropical Medicine, Mahidol University, Bangkok, Thailand \& Academic Medical Center, University of Amsterdam, Amsterdam, the Netherlands), Ary Serpa Neto (Hospital Israelita Albert Einstein, São Paulo, Brazil), and Jacobus Preller (Addenbrooke's Hospital, Cambridge University Hospitals NHS Foundation Trust, Cambridge, UK).

\section{Compliance with ethical standards}

\section{Conflicts of interest}

All the authors declare no conflict of interest.

\section{Open Access}

This article is distributed under the terms of the Creative Commons Attribution-NonCommercial 4.0 International License (http://creativecommons.org/ licenses/by-nc/4.0/), which permits any noncommercial use, distribution, and reproduction in any medium, provided you give appropriate credit to the original author(s) and the source, provide a link to the Creative Commons license, and indicate if changes were made.

Received: 7 March 2017 Accepted: 2 May 2017

Published online: 15 June 2017
References

1. Rhodes A, Evans LE, Alhazzani W, Levy MM, Antonelli M, Ferrer R, Kumar A, Sevransky JE, Sprung CL, Nunnally ME, Rochwerg B, Rubenfeld GD, Angus DC, Annane D, Beale RJ, Bellinghan GJ, Bernard GR, Chiche JD, Coopersmith C, De Backer DP, French CJ, Fujishima S, Gerlach H, Hidalgo $J$, Hollenberg SM, Jones AE, Karnad DR, Kleinpell RM, Koh Y, Lisboa TC, Machado FR, Marini JJ, Marshall JC, Mazuski JE, Mclntyre LA, McLean AS, Mehta S, Moreno RP, Myburgh J, Navalesi P, Nishida O, Osborn TM, Perner A, Plunkett CM, Ranieri M, Schorr CA, Seckel MA, Seymour CW, Shieh L, Shukri KA, Simpson SQ, Singer M, Thompson BT, Townsend SR, Van der Poll T, Vincent JL, Wiersinga WJ, Zimmerman JL, Dellinger RP (2017) Surviving Sepsis Campaign: international guidelines for management of sepsis and septic shock: 2016. Intensive Care Med 43(3):304-377

2. Dunser MW, Festic E, Dondorp A, Kissoon N, Ganbat T, Kwizera A, Haniffa R, Baker T, Schultz MJ, Global Intensive Care Working Group of European Society of Intensive Care Medicine (2012) Recommendations for sepsis management in resource-limited settings. Intensive Care Med 38:557-574

3. Schünemann H, Brożek J, Guyatt G, Oxman A (eds) (2013) GRADE handbook for grading quality of evidence and strength of recommendations. Updated October 2013. The GRADE Working Group. www.guidelinedevelopment.org/handbook. Accessed 6 Jan 2017

4. Serpa Neto A, Schultz MJ, Festic E (2016) Ventilatory support of patients with sepsis or septic shock in resource-limited settings. Intensive Care Med 42:100-103

5. Guyatt GH, Alonso-Coello P, Schunemann HJ, Djulbegovic B, Nothacker M, Lange S, Murad MH, Akl EA (2016) Guideline panels should seldom make good practice statements: guidance from the GRADE Working Group. J Clin Epidemiol 80:3-7

6. Hashmi M, Khan FH, bin Sarwar Zubairi A, Sultan ST, Haider S, Aftab S, Husain J, ul Haq A, Rao ZA, Khuwaja A, Sultan SF, Rais Z, Baloch R, Salahuddin N, Khan A, Sultan F, Chima K, Ali A, Ali G (2015) Developing local guidelines for management of sepsis in adults: sepsis guidelines for Pakistan (SGP). Anaesth Pain Intensive Care 19(2):196-208

7. Mukherjee JJ, Chatterjee PS, Saikia M, Muruganathan A, Das AK, Diabetes Consensus Group (2014) Consensus recommendations for the management of hyperglycaemia in critically ill patients in the Indian setting. J Assoc Physicians India 62:16-25

8. Jacobson BF, Louw S, Buller H, Mer M, de Jong PR, Rowji P, Schapkaitz E, Adler D, Beeton A, Hsu HC, Wessels P, Haas S, South African Society of Thrombosis and Haemostasis (2013) Venous thromboembolism: prophylactic and therapeutic practice guideline. S Afr Med J 103:261-267

9. Panahi Y, Mojtahedzadeh M, Zekeri N, Beiraghdar F, Khajavi MR, Ahmadi A (2011) Metformin treatment in hyperglycemic critically ill patients: another challenge on the control of adverse outcomes. Iran J Pharm Res 10:913-919

10. Mojtahedzadeh M, Jafarieh A, Najafi A, Khajavi MR, Khalili N (2012) Comparison of metformin and insulin in the control of hyperglycaemia in non-diabetic critically ill patients. Endokrynol Pol 63:206-211

11. Ansari G, Mojtahedzadeh M, Kajbaf F, Najafi A, Khajavi MR, Khalili H, Rouini MR, Ahmadi H, Abdollahi M (2008) How does blood glucose control with metformin influence intensive insulin protocols? Evidence for involvement of oxidative stress and inflammatory cytokines. Adv Ther 25:681-702

12. Smoyer WE, Finkelstein FO, McCulloch MI, Carter M, Brusselmans A, Feehally J (2016) "Saving Young Lives" with acute kidney injury: the challenge of acute dialysis in low-resource settings. Kidney Int 89:254-256

13. Maitland K, Kiguli S, Opoka RO, Engoru C, Olupot-Olupot P, Akech SO, Nyeko R, Mtove G, Reyburn H, Lang T, Brent B, Evans JA, Tibenderana JK, Crawley J, Russell EC, Levin M, Babiker AG, Gibb DM, FEAST Trial Group (2011) Mortality after fluid bolus in African children with severe infection. N Engl J Med 364:2483-2495

14. Murray MJ, DeBlock H, Erstad B, Gray A, Jacobi J, Jordan C, McGee W, McManus C, Meade M, Nix S, Patterson A, Sands MK, Pino R, Tescher A, Arbour R, Rochwerg B, Murray CF, Mehta S (2016) Clinical practice guidelines for sustained neuromuscular blockade in the adult critically ill patient. Crit Care Med 44:2079-2103

15. Critical Care Nutrition at the Clinical Evaluation Research Unit (CERU) (2015) Clinical practice guideline for nutrition support in the mechanically ventilated, critically ill adult patient. CERU, Kingston General Hospital/Queen's University. http://www.criticalcarenutrition.com/. Accessed 6 Jan 2017 